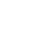

\title{
Rethinking Russian pan-Slavism in the Ottoman Balkans: N.P. Ignatiev and the Slavic Benevolent Committee (1856-77)
}

\section{Aslı Yiğit Gülseven}

To cite this article: Aslı Yiğit Gülseven (2017) Rethinking Russian pan-Slavism in the Ottoman Balkans: N.P. Ignatiev and the Slavic Benevolent Committee (1856-77), Middle Eastern Studies, 53:3, 332-348, DOI: 10.1080/00263206.2016.1243532

To link to this article: https://doi.org/10.1080/00263206.2016.1243532

\section{曲 Published online: 26 Oct 2016.}

Submit your article to this journal $\sqsubset$

Џlll Article views: 354

Q View related articles $\square$

View Crossmark data 〔 


\title{
Rethinking Russian pan-Slavism in the Ottoman Balkans: N.P. Ignatiev and the Slavic Benevolent Committee (1856-77)
}

\author{
Aslı Yiğit Gülseven \\ History Department, Bilkent University, Ankara, Turkey
}

The period between the Crimean War of 1853-56 and the Russo-Turkish War of 1877-78 was one of the most important periods to leave its mark on the second half of the nineteenth century. This interwar period significantly affected international developments across Eastern Europe, Russia and the Ottoman Empire at the end of the nineteenth century and beginning of the twentieth century. In that period, the dominant feature of Russian foreign policy towards the Ottoman Balkans was its pan-Slavic inclinations. Russian official policy in that period, however, was distant from the pan-Slavic movement. The principal reason for this discrepancy was the pan-Slavic policies pursued by Russian Ambassador to Constantinople Nikolai Pavlovich Ignatiev and the Slavic Benevolent Committee, which ultimately shaped Russia's Balkan policy. Thus, in analysing Russia's Balkan policy in the interwar period, these two actors deserve particular attention.

From the early twentieth century onwards, a number of scholarly studies have addressed the subject of Russia's pan-Slavic policies in the nineteenth century. These studies have, for the most part, either described the general political situation in Europe and the Balkans or focused on specific national, cultural or event-based themes. In Russia, many archives were only opened in the early 1990s. Therefore, prior to that time most studies on pan-Slavism did not incorporate Russian archival sources, or they could only benefit from the archives of other states. ${ }^{1}$ These early studies focused on Russian expansionist policies and the pan-Slavic views of Russian philosophers and writers such as Nikolai Yakovlevich Danilevskii, Fyodor Mikhailovich Dostoevskii, Ivan Sergeevich Aksakov and Rostislav Andreevich Fadeev ${ }^{2}$ More recent studies have included biographical works, such as those by Viktoriia Khevrolina, David MacKenzie and Ozhan Kapici. ${ }^{3}$ These studies concentrate on Ignatiev's military and diplomatic career and activities. Although these works touch on Russia's pan-Slavic policies in the Balkans, their focus is rather on offering a general evaluation of the period's international relations. Denis Vovchenko and Jelena Milojkovic-Djuric have studied the formation of national identity among Balkan Slavs and the Russian influence on this process, discussing the national identity of the Balkan Slavic people in the context of pan-Slavism and Russian Orthodoxy. ${ }^{4}$ Only a few studies have directly addressed the Slavic Benevolent Committee, including those by Sergei Nikitin, Aleksei Popovkin and Zdenko Zlatar. ${ }^{5}$ They describe the administrative and institutional establishment of the Committee, but restrict themselves to matters concerning foreign policy. Nikitin, a Soviet historian, downplayed the committee's role as a political actor in the Balkans 
and criticized Western historiography for exaggerating the relation between the Slav Committee and the Russian government. One of the most recent studies on the Slavic Benevolent Committee was published in Sofia, by Andrei Andreev, who concentrated on the cultural activities of the committee, especially in the form of its support for the Bulgarian independence movement and education. ${ }^{6}$

Although all of these studies have made valuable contributions to the general literature, they all either lack Russian and Ottoman archival sources or focus narrowly on issues, like administrative policy, that neglect the impact of pan-Slavism and the form it took in the Ottoman Balkans between 1856 and 1877. Additionally, they limit themselves to evaluating Russia's policy towards the Ottoman Empire from the perspective of Russian official foreign policy and Russia's relations with European states in the second half of the nineteenth century. In this article I aim to draw attention to Pan-Slavism's evolution as a political asset from the perspective of two specific Russian actors: Ambassador N.P. Ignatiev and the Slavic Benevolent Committee. These actors' strategies towards spreading Russian influence in the Balkans and their relations with Russian official policy will be the subject of this article.

In order to understand the importance of the impact of Ignatiev and the Slavic Committee on the making of foreign policy, one must first appreciate the changes that took place in the realm of Russian foreign policy from the era of Nicholas I to Alexander II. The Russian state had proved successful during the final stage of the Napoleonic Wars, and this raised its prestige among the European Powers. Tsar Nicholas I's $^{7}$ foreign policy focused on preserving the European status quo to prevent another war on the continent. ${ }^{8}$ In part as a result of this effort, Russia found itself involved in the Crimean War, which was a turning point for Tsarist diplomacy in the second half of the nineteenth century. Russian failure in the war revealed its military and economic backwardness ${ }^{9}$, and diminished Russian prestige in the international arena. Following the Paris Peace Treaty, in an effort to save its prestige, Russia made a policy adjustment: moving away from Tsar Nicholas I's interventionist principles and towards a more peaceful and quiescent strategy. In April 1856, Alexander Mikhailovich Gorchakov, the former Russian ambassador to Vienna, was appointed to revise Russia's foreign policy objective in order to raise the country's prestige. Although Gorchakov was eager to reformulate the clauses of the Paris Peace Treaty, ${ }^{10}$ his diplomacy tended towards non-aggressiveness. ${ }^{11}$

After the Crimean War, Russian economic and political backwardness vis-à-vis Europe pushed Russia to increase the efficiency of its diplomatic and consular services. ${ }^{12}$ Therefore, the diplomatic staff of the Asiatic Department of the Russian Foreign Office were chosen carefully for their regional and technical background. ${ }^{13}$ Appointees to the Ottoman Empire constituted the highest percentage of the department's Foreign Service personnel, and it was this Asiatic Department that received reports related to the situation of Ottoman Christian subjects from the diplomatic personnel in Constantinople and the Slavic Benevolent Committee. ${ }^{14}$ During the 1860 s and 1870 s Pan-Slavic sentiments became especially pronounced in these reports, revealing that Pan-Slavism had begun to affect Russian diplomats.

Prior to the Crimean War, Pan-Slavism had not experienced widespread official or public support. Yet, in the face of the difficult economic conditions of the mid-1870s, Russia experienced a surge of pan-Slavic sentiment. ${ }^{15}$ In this period, Russian diplomacy under 
Gorchakov focused on maintaining Russia's international credibility in order to re-direct public opinion from domestic problems to the international realm.

In such an international environment Russia needed a period of peace for its military and economic recovery. However, by the mid-nineteenth century, pan-Slavism had moved away from its former, predominantly cultural character and came to take on an increasingly political demeanour. The rise of political pan-Slavic thought ran counter to and ultimately upended Gorchakov's strategy of staying away from international conflicts in order to secure breathing room for the project of Russian modernization.

In this article, I argue that in the second half of the nineteenth century, despite Russia's official policy of avoiding conflict with the West, pan-Slavism took on a political character and began to act as an asset of Russian imperial ideology in the Ottoman Balkans. This ideology was visible basically at two levels. At the personal level, in the case of N.P. Ignatiev ${ }^{16}$ and his diplomatic mission in Turkey (1864-77), and at the institutional level, in the case of the Slavic Benevolent Committee, this ideology served to spread Russian influence among the Slavic Orthodox subjects of the Ottoman Sultan. ${ }^{17}$

This article is divided into four parts: the first describes the differences between Western pan-Slavic thought and Russian pan-Slavism, as well as the evolution of Slavophilism into political pan-Slavic thought. The next part of the article defines Ignatiev's diplomatic methods and pan-Slavic mindset towards the Ottoman Balkans. Rather than simply following St. Petersburg's instructions, Ignatiev generally pursued his own initiatives, and thus represents the personal level of pan-Slavic propaganda in the region. The third part will address the Slavic Benevolent Committee, which represents the institutional level of that propaganda effort. The fourth part will discuss the Ottoman administration's efforts to counter Russia's propaganda activities towards its Slavic Orthodox subjects. Finally, the article will evaluate the role of Ignatiev and the Slavic Benevolent Committee's pan-Slavic activities in the Balkans and how this affected official Russian aims in the region.

The roots of pan-Slavic ideology date back to the Western Slavs in the seventeenth century, when the Western and Southern Slavs first desired to unite on an ethnic and cultural basis without being tied to a particular imperial force. In the nineteenth century, nationalist and romantic intellectual circles throughout Western and Central Europe re-appropriated earlier seventeenth-century works on the idea of creating a Slavic Union. With the impact of the French Revolution, Croatians, Slovaks, Slovenians, Serbs and Bulgarians, all of whom lived under imperial supremacy, began to endeavour to secure their independence. ${ }^{18}$ Although their efforts and writings were nationalistic and separatist in nature, they did not seek to establish supremacy one over another.

Napoleon's invasion of Moscow in 1812 increased nationalist sentiment among the Russian public. The Russian activist group 'United Slavs' ${ }^{19}$ (Obshestva Soedinennykh Slavian) desired to create a Slavic Union, but ultimately failed to achieve anything more than the Dekabrists had. Later, sympathizers of another Russian intellectual movement, the Slavophiles, followed in the footsteps of the United Slavs. These Slavophiles, though ostensibly acting in support of the general idea of Slavic cultural unification, in practice always worked in the name of increasing Russian superiority over all Slavs. ${ }^{20}$ The eminent Russian Slavophile Aleksei Stepanovich Khomiakov asserted that hostile powers (namely Romanians, Hungarians, Germans, Greeks, Turks and Albanians) were located all along the southern and eastern borders of the different Slavic groups, and their unification would 
threaten Russian sovereignty in the region; therefore, the only solution would be to unite them under the guidance of Russia, and make Russia the natural centre of the Slavic world. Public opinion, however, saw the imperialistic ambition behind Khomiakov's panSlavism, and neither Western Slavs nor the Tsarist government would accept it. ${ }^{21}$ These activists believed that they had to preserve Slavic Orthodox civilization against the influence of the Catholic West. ${ }^{22}$ According to them, this could only be realized through a panSlavic federation under the leadership of the Russian emperor with Constantinople as its centre. Yet, during and after the Crimean War, Russian state authorities and intellectual circles embarked upon a proactive endeavour to bring the forces of the Slavic brotherlands under imperial Russian leadership against the European West. ${ }^{23}$

All the efforts of the Western Slavs were for the sake of developing the national consciousness of each group of Slavic people; the idea of the superiority of one Slavic group over another was not part of their intellectual agenda. On the other hand, Russian intentions were oriented mostly towards liberating them to expand Russian influence and serve Russian interests.

To understand the form pan-Slavism took in the Russian political sphere, one must comprehend its cultural and ideological dimensions, which in turn requires an examination of its historical, philosophical, and political roots. ${ }^{24}$ Since the eighteenth century, Russian intellectuals had sought to reshape their cultural roots. As part of the Romantic agenda of the nineteenth century, they began to strengthen their ties with Russian folk culture and distancing themselves from European culture. The noble class became aware of the state's backwardness, and they considered the only solution to be the development of an educated elite class that was less 'European' and more 'Russian'. As a response to the 'material enlightenment' of Europe, Slavophilism offered a 'spiritual enlightenment'. Thus, throughout the end of the eighteenth and beginning of the nineteenth century Slavophilism found an intellectual base among the educated class. This was not a political but a purely cultural phenomenon, focused on Russian culture, which had two fundamental aspects: Pravoslavie (Orthodox Christianity) and Slavdom (union of Slavic people). ${ }^{25}$

Slavophilism emerged in the 1830s during the reign of Nicholas I. Due to the tsar's repressive policies, Slavophiles failed to come up with a complete cultural program. Dedicated to Russian culture, they accepted Moscow as their centre rather than St. Petersburg in a fashion reminiscent of Tsar Peter l's westernization reforms and the German influence on the Russian bureaucracy during the period. ${ }^{26}$ In that sense, it was not a coincidence that Pan-Slavism and, later, the Slavic Benevolent Committee, with their anti-Western and anti-Catholic feelings, chose Moscow as their centre.

During Nicholas I's reign, Russian intellectuals were prejudiced towards Orthodoxy and Slavdom, because the popular tendency of that era was European-oriented. However, the death of Nicholas I (1855) was a turning point for the development of Slavophilism. By that time, Russian society had already split into two factions, radicals and conservatives, with the latter seeking to preserve 'autocracy' rather than fight for revolutionary change. ${ }^{27}$ These factions later were transformed into separate political and cultural groups, one of which was pan-Slavists. Although pan-Slavists' starting point was the same as Slavophiles, namely the cultural and moral enlightenment of Russian society, over the course of time it became politicized around the Balkan issue. Ivan Vasilyevich Kireevsky and Aleksei Stepanovich Khomiakov, the fathers of Slavophilism, formulated pan-Slavism on the basis of 
religion and culture; yet, between the lines, this cultural connection carried the potential of a Slavic Union under the Russian leadership of a 'Vseslavianskii Tsar' (Emperor of all Slavs). ${ }^{28}$ On the other hand, at the very beginning, Slavophiles did not espouse the idea of Russian domination over the Slavic nations. But over the course of the political developments of the nineteenth century, their ideology began to turn towards becoming the predominant power in the world. As a result, the culturally oriented Slavophile idea gave way to a pan-Slavic political and diplomatic agenda. ${ }^{29}$

Throughout the 1860s pan-Slavic ideology spread among the Russian bureaucrats, and its most ardent representative was N.P. Ignatiev. His primary goal was to reverse the degrading terms of the Paris Treaty, and to change the destiny of Bessarabia in parallel with Russia's interests. ${ }^{30}$ Ignatiev used pan-Slavic ideology as a foreign policy tool in his relations with the Austrian and Ottoman Slavs to reach his goals. In the mid-nineteenth century, the pan-Slavic movement spread among intellectuals, whose motivations were mostly cultural and religious. However, that ideology did more to serve the interests of the Russian political class in their quest for dominance in the Balkans than it did to protect their Slavic brothers and coreligionists.

Pan-Slavic ideology had a limited impact on tsarist foreign policy during the interwar period (1856-77). The European-minded Minister of Foreign Affairs Gorchakov ${ }^{31}$ was not in favour of nationalistic sentiments, which had the potential to overshadow the relationship between Russia and the West. ${ }^{32}$ Gorchakov's concerns were visible in his policy of censorship towards pan-Slav journals. ${ }^{33}$ Karl Vasilievich Nesselrode, the Minister of Foreign Affairs (1822-56), stood behind preserving the European balance of power, as did the Austrian diplomat Metternich, one of the main actors of the Congress of Vienna (1815). Both of them considered radical nationalist movements as one of the main threats to the European balance of power established during the Congress. In that sense, pan-Slavic ideas were banded together with the liberal and national ideas widespread in central and Western Europe in the 1830s and 1840s. In this, Gorchakov followed the same internal and external political line as had his predecessor Nesselrode, and considered Ignatiev's panSlavic attitudes as an untimely and misguided exercise in bravado. ${ }^{34}$

Under the administration of Alexander II and Gorchakov, pan-Slavists generally lacked official support. Thus, in that period they were known more for their cultural activities than for their political acts. Since Russia's foreign policy aimed to avoid complications with Europe, Russian official circles strove to distance themselves from any radical tendency. ${ }^{35}$ The government was especially afraid of the idea of a Slavic Union under Russian leadership. ${ }^{36}$ Nevertheless, Ignatiev's diplomacy was different from the official Russian policy of the interwar period (1856-77).

On personal level, Ignatiev was the most influential representative of Russian Pan-Slavism in diplomacy. ${ }^{37}$ From the beginning of his diplomatic career in Constantinople in 1864, his activities were orientated towards exploring the vulnerable situation of Orthodox Slavs under Ottoman rule. ${ }^{38}$ Before becoming Russian ambassador in Constantinople, during his tenure as director of the Asiatic Department (1861-64) he believed that the most significant goal for Russia on the international stage would be to revise the Paris Treaty and to strengthen the Russian position over the Straits. He also believed in the future importance of the support of the Balkan Slavs and the need to organize them under Russian 
political guidance. According to him, the territory of Bessarabia - lost at the Paris Peace Treaty - should be returned to Russia; moreover, the neutral status of the Black Sea and the limitations on Russian naval forces in it should be annulled. ${ }^{39}$ Though Ignatiev's political project had much in common with Gorchakov's ideas in regards to the Paris Peace Treaty, they differed in terms of their diplomatic methods. ${ }^{40}$ Gorchakov followed a traditional diplomatic approach, giving primacy to bargaining, while Ignatiev was in favour of informal and personal contact with the Ottoman bureaucrats and the Sultan himself. ${ }^{41}$ Although Gorchakov was also uncomfortable with the Paris Treaty's degrading conditions, his diplomatic intentions lay at odds with those of Ignatiev. Gorchakov was an enthusiastic admirer of the 'Concert of Europe', and considered it to provide a real basis for successful diplomacy. In contrast, Ignatiev distrusted the European powers and believed they were trying to isolate Russia by forming an 'anti-Russian coalition' ${ }^{42}$

In 1861, Ignatiev was appointed as the director of the Asiatic Department. ${ }^{43}$ During his first years at the department, Ignatiev maintained close relations with pan-Slav circles through Ivan Sergeevich Aksakov (1823-86), Vladimir Aleksandrovich Cherkassky (182478), Fyodor Ivanovich Tiutchev (1803-73) and Yurii Fyodorovich Samarin (1819-76). ${ }^{44}$ In parallel with his nationalist views, Ignatiev formulated a Russian foreign policy opposing Catholic and Protestant influences in the Balkans. ${ }^{45}$ He believed 'Russia should keep its hand on these nations' ${ }^{\prime 6}$ to preserve Russia's strategic interests. From the perspective of Russia's contemporary political plans concerning the Ottoman Balkans, Ignatiev's panSlavism differed totally from the earlier Slavophilism of the 1840s and 1850s. Rather than a cultural movement, for him pan-Slavism meant strengthening Russian positions in the Balkans and Near East. He was convinced that Russia remained isolated and in danger of losing its influence in south-eastern Europe because of the Paris Peace Agreement. He indicated that although the Crimean War had been fought to increase Russian glory in the international arena, in practice it resulted in a total loss of prestige. ${ }^{47}$

Before his appointment to Constantinople, Ignatiev had already adopted a course of action aimed at increasing Russian influence in the Balkan Peninsula. Throughout his tenure at the Asiatic Department, Ignatiev laid the foundations for his diplomatic actions during his ambassadorship in Constantinople. ${ }^{48}$ In a secret letter to Gorchakov, Ignatiev drew attention to two important tasks: soothing tensions among the Serbian, Montenegrin, Bulgarian and Greek peoples and preventing a possible alliance between the Serbian and Montenegrin Slavs under Habsburg authority. He opined that the pro-Russian Serbian Prince Mikhail could be the head of a future Serbo-Bulgarian state, while the Bulgarians could only be a 'raw-material, as they lack well-educated elite. ${ }^{49}$ In 1866/67 he wrote that the Balkan people - including Greeks, Montenegrins, Serbians and Albanians - had become closer and that a general Orthodox-Slav revolt against Ottoman rule had become a real possibility. However, for Ignatiev, the critical point was the possibility of Western interference in Balkan affairs; and in that unwanted case Russian foreign policy both in the Balkans and in the Ottoman Empire would have been jeopardized. Ignatiev believed that the Orthodox Slavs should never gain their independence without Russian help; therefore, until they were ready, Russia should work to preserve its influence in the region and encourage them to rise against the Porte at the right moment, in accordance with Russia's imperial interests. ${ }^{50}$

Ignatiev desired to be appointed to the Constantinople mission in order to freely conduct his own diplomatic strategy at the Porte. ${ }^{51}$ Actually, his appointment to 
Constantinople was the first diplomatic triumph of pan-Slavism. ${ }^{52}$ Russia's Balkan affairs moved into a new stage after Ignatiev began to apply his ambitious plans concerning the Ottoman Balkans. Nevertheless, there were some bureaucratic limits on pan-Slavism that indicate the ideology was not officially supported by St. Petersburg, at least during the interwar period (1856-77). ${ }^{53}$ Ignatiev's ambitious plans caused tension between him and Petr Nikolaievich Stremoukhov, the head of the Asiatic Department between 1864 and 1875. ${ }^{54}$ Moreover, European-oriented Russian diplomatic circles headed by Minister of Foreign Affairs Gorchakov were suspicious of Ignatiev's actions, which risked triggering national movements in the Balkans. A number of Russian experts in Balkan affairs found Ignatiev's plans to be troubling, including Minister of War Dimitrii Alekseevich Miliutin, Minister of Finance Count Mikhail Khristoforovich Reitern and Aleksandr Mikhailovich Gorchakov, as well as many diplomats. ${ }^{55}$

At the institutional level, an important actor that played a significant role in Russia's Balkan political strategy was the Slavic Benevolent Committee. Pan-Slavism took on an institutional form with the formation of the Moscow Slavic Benevolent Committee (Moskovskii Slavianskii Blogatvaritelnyi Komitet) ${ }^{56}$ in 1858. After the Crimean defeat, the Russian Foreign Ministry aimed at increasing Russia's relations with the Balkan states. To this end, the Slavic Benevolent Committee was founded under the management of the Asiatic department. At the end of the 1850s, pan-Slavic propaganda began to gain importance partially as a result of the initiatives of that institution. Within ten years the Committee expanded its activities and increased its administrative manpower. ${ }^{57}$ Three other branches emerged out of the committee: the St. Petersburg Committee in 1868, the Kiev Committee in 1869 and the Odessa Committee in $1870 .^{58}$ While the members of the St. Petersburg Committee were high-ranking bureaucrats and army officers, the Moscow Committee members included Slavophile elites from business and intellectual circles. ${ }^{59}$ While the Moscow Slavic Committee initially had few members, thanks to its networking strategy it managed to establish close contacts within different strata of society, including influential bureaucrats. These social connections developed the committee's efficiency and area of influence both in Russia and in the Balkans during the 1870s. ${ }^{60}$

Aleksei Nikolaevich Bahmetev (1798-1861) was the head of the Moscow Slavic Committee between 1860 and 1861. After his death, he was replaced by Mikhail Petrovich Pogodin (1800-75). Pogodin soon became one of the leading proponents of the politicization of pan-Slavism, and was the first person to espouse the idea of a Slavic Union, even before Nikolai Yakovlevich Danilevskii (1822-85). Pogodin used the journals he published to attract the attention of Slavophiles. ${ }^{61}$ In 1854, in the midst of the Crimean War, he came up with the idea of a Danubian Union (Dunaiskii Soiuz), which was to comprise Hungary, Greece, Moldova, Valachia and Transilvania. According to Pogodin, Constantinople was to be the centre of this union and Russia its head. His project is widely accepted as a milestone in the movement towards cultural and political Slavic unification and as paving the way for future Russian political pan-Slavic propaganda. During Pogodin's leadership between 1861 and 1875, the committee strengthened its connection with pan-Slavist intellectuals and scientists abroad, which helped it to establish ties with the Western Slavs. He intended to incite European and Slavic public opinion over the situation of Orthodox Slavs under Ottoman rule. Thus, the 'Slav question' began to be mentioned as a subtitle of the Eastern Question. ${ }^{62}$ 
The main activities of the Slavic Committee can be classified as donating to Balkan Orthodox schools, establishing Slavic centres in public libraries, funding Orthodox Slav students from the Balkans for their education in Russia, collecting donations from wealthy people, organizing public activities for monetary support and publishing newspapers ${ }^{63}$ in Russia to propagate Russian pan-Slavism. In order to maintain the smooth functioning of the committee, both in terms of money and material, its financial records were strictly kept. ${ }^{64}$ Russian Balkan missionaries in the field used these committee funds for propaganda purposes. Their main purpose was to create local followers of Russian pan-Slav and imperial policies in the Balkans. In its early years, the committee succeeded in establishing a useful network of close relations with the members of consulates and officers of the Asiatic Department. ${ }^{65}$ All these educational, publishing and funding activities aimed at enhancing Russian cultural and political weight and influence in the Balkans. For instance, the committee insisted that correspondence between individuals in the Balkans and the committee had to be carried out in Russian. ${ }^{66}$ These activities served to spread a Russiancentred pan-Slav atmosphere in the Ottoman Balkans.

The Russian government obtained information about the situation in the Ottoman Empire through the Asiatic Department and the Russian Embassy in Constantinople. On this point, the Slavic Benevolent Committee's actions were in accordance with the government. The existence of an organizational body active in the Balkans that was independent from the official administration provided Russian bureaucratic elites with advantage, as they would not share responsibility for the committee's actions. ${ }^{67}$ The Asiatic Department controlled each donation and every act of the committee, and it regularly requested information concerning the progress of the Slav beneficiary students. ${ }^{68}$ The Russian government paid special attention to these beneficiaries, whom it envisioned as future Russophile activists in the region. The Balkan Slavs who were sent to Moscow specialized in such areas as theology, medicine, law and philology. Graduates of these fields moved onto careers in these various specializations that brought them in close contact with the public. It is therefore no coincidence that the committee preferred to support students in these particular fields. These students, in their letters to the committee, promised to return to their homelands after finishing their education in Russia, and the Russian high administration paid great importance to this. ${ }^{69}$ Russian officials believed the Slavic students who were educated in Russian would imbibe its culture and language, and in the future would serve as the main supporters of Russian political and military activities against the Porte. Where prior to the committee's foundation Russian agents were provoking Bulgarian peasants to refuse to pay their taxes and to rise against the Porte, ${ }^{70}$ after the establishment of the Slavic Benevolent Committee, Russia's strategy for strengthening its active position in the Balkans shifted to a higher level.

Both Ignatiev and the Slavic Benevolent Committee focused on Bulgaria in their activities. ${ }^{71}$ The Bulgarian instructors (uchiteli) who were sent to Moscow by the committee for their higher education upon their return would teach partially in the Russian language in Bulgarian schools. ${ }^{72}$ It was for this reason that Ignatiev paid special attention to ensure that Bulgarian students were awarded bursaries from the committee. ${ }^{73}$ These students, upon their return to their own country, became Russophile activists and supporters of Russian policies in the Balkans. ${ }^{74}$ In practice, the committee's primary concern was far removed from the formation of a national consciousness amongst the Orthodox Slavs 
under Ottoman rule. Most of the donations and scholarships were oriented towards the support of either Orthodox Christianity or Russian culture and language. These attempts contributed to Russia's interests rather than helping either the Bulgarians or other Slavic peoples to develop their own national unity. ${ }^{75}$

The Ottoman authorities, for their part, were critical about these developments. They understood that the Bulgarians, especially the Russophiles, would become an instrument in the hands of Russian politicians. ${ }^{76}$ They were aware that the committee would try to increase Russian influence amongst Bulgarians through its educational activities. Accordingly, the Ottoman administration tried to address the situation so as to avoid jeopardizing Ottoman territorial integrity and the success of the Tanzimat reforms. ${ }^{77}$ European governments were also uncomfortable with Russia's plans in the Balkan Peninsula. France and England paid special attention to Ignatiev's personal relations with the Ottoman palace and Grand Vizier Mahmud Nedim Paşa. They preferred to keep the Ottoman administration free of Russian influence, which they felt would hamper Western interests. $^{78}$

The Slavic Benevolent Committee's actions and Ignatiev's diplomatic and personal attempts threatened the Tanzimat reforms and aimed at supporting national movements that would eventually serve tsarist interests. On the other hand, Western pan-Slavic ideas acted mainly in the name of the cultural unity of the Balkan peoples, bolstering and supporting the ethnic and national sentiments of each group. For example, Croatian bishop Josip Juraj Strossmayer, who worked for the idea of Slavic unification in the Balkans, supported the idea of the equality ${ }^{79}$ of all Slavic nations and groups, and believed that Europe should not consider them as 'éléments étrangers' ${ }^{\prime 80}$ living in the continent. According to him, the Eastern Question should be solved on the basis of Christianity and freedom by supporting the Southern Slavs, in accordance with the way Western Europe supported other Christian communities. ${ }^{81}$ Specifically in the Bulgarian case, though he was a Catholic bishop, Strossmayer admired the idea of an independent Bulgarian Church, and considered a nation-centred solution to the Bulgarian Church Question. ${ }^{82}$ As a part of his cultural activities in that field, he collected and supported the publication of Bulgarian folk songs at his own expense. ${ }^{83}$ Prominent among the other intellectuals who contributed to the development of Bulgarian national awareness were the Miladinov brothers from Western Macedonia, who collected Bulgarian folk songs and poems, ${ }^{84}$ the Czech-Bulgarian archaeologists Hermengild and Karel Skorpil, ${ }^{85}$ the Czech historian and politician Konstantin Irechek $^{86}$ and Ivan Mrkvicka, ${ }^{87}$ who contributed to national art and painting in Bulgaria. This is to say that while Russia's activities were mainly oriented towards ending Ottoman rule and increasing its own influence in the Balkan Peninsula, Western Slavs' cultural efforts had a very different goal, namely improving their own national consciousness. ${ }^{88}$

Russia's view of Eastern Slavs as inferiors that should obey Russian supremacy can be observed in the statements of nineteenth-century Russian historian Vladimir Ivanovich Lamanskii at the Slavic Ethnographic Exhibition in 1867. Lamanskii stated that Russia wanted to include non-Russian Slavs into its ethnographic exhibition not because it believed that their Slavic character was equal to that of Russian Slavs, but instead because Russia wanted to be kind to 'these weak Slav brothers' by granting them this historical and ethnographical right. He thought that this would make Russia a strong leader for the Slav nations and that the Russian language would be the official language among them. 
According to him, this type of pan-Slavism would only bring a Russification rather than an equal brotherhood. ${ }^{89}$

The Ottoman administration was aware that Ignatiev's diplomacy and the Committee's activities would eventually cause internal disturbances. European governments ${ }^{90}$ also warned the Ottomans about this danger. ${ }^{91}$ Ottoman sources from the period reveal that the Ottoman administration was aware of Russia's activities. One such source is the memoires of Midhat Paşa. Midhat Paşa was the first Ottoman governor of the Danubian vilayet (province), ${ }^{92}$ where he enacted a series of administrative reforms. He tried to modernize the education system in the province for both Bulgarians and the Turks. He also established a bilingual provincial newspaper, published in Turkish and Bulgarian, in Tuna (Dunav) and conducted a financial administrative reform program in the province. Midhat Paşa's modernization project served at once to develop the province and to create a barrier against Russian intentions in the region. ${ }^{93}$ He wrote that in 1866 in Kiev, Bucharest and Kishinev a number of Slavic committees had worked to raise armed groups to provoke Bulgarians to revolt against the government. He complained that Russians were encouraging and funding thousands of Bulgarian students to receive an education in Russia, and that all of these students were returning to Bulgaria to work as agents spreading Russian propaganda. He additionally wrote that Russian propaganda, through its great number of publications, was working to poison European public opinion against the Ottomans concerning the situation of Bulgarians under Ottoman rule. He emphasized that in these activities Ignatiev played the most significant role. ${ }^{94}$

Compared to the Slavic Benevolent Committee's propaganda, Ignatiev's personal and unofficial efforts among both locals and the Ottoman bureaucracy produced more direct and proactive results for Russia's Balkan policy. Ignatiev did not strictly follow the official Russian policy towards the Ottoman state; his diplomatic and military tactics were different from the central orders he received. From time to time Gorchakov would send warning letters to Ignatiev in order to make him follow state policy rather than his own initiatives. ${ }^{95}$ Even Stremoukhov, the head of the Asiatic Department, who became aware of Ignatiev's secret activities after he received a report from the Russian agent Naiden Gerov in 1867, grew restless about Ignatiev's secret financial and political support to the Bulgarian revolutionary committees in Bucharest. ${ }^{96}$

Ignatiev considered the success of the Tanzimat reform as one of the biggest threats to Russian political plans in the Balkans. In his memoires, Ignatiev wrote that if the reforms had achieved their aims it would have meant equality and prosperity in the everyday life of the Balkan Slavs. In other words, the success of the Tanzimat would have weakened Russia's hand in the region. ${ }^{97}$ Thus, in order to undermine the success of the reforms he felt it was necessary to intensify anti-Ottoman propaganda. ${ }^{98}$ On this point, Ottoman reports from the Tuna provincial authorities included many complaints concerning Ignatiev's plans to incite a Bulgarian rebellion against the Porte. ${ }^{99}$ These situations were not limited to the Russian ambassador's intrigues. From letters addressed to the Benevolent Committee, it becomes clear that as a result of Russian propaganda, armed groups began to emerge amongst the Bulgarians and Serbs. ${ }^{100}$ Armed banditry in Rumelia was a common occurrence and a significant problem for the Ottoman authorities, but in these propaganda letters the Turkish banditry groups were described as killers and a bane to the Bulgarian population. The same bandits from the Bulgarian or Serbian side, however, 
were proclaimed as freedom fighters, and these freedom fighters were portrayed as constituting the vanguard that would go on to form the basis of national liberation movements. ${ }^{101}$ Russia approached these 'freedom fighters' with sympathy, as they were agents that aided in disrupting the rule of the Ottoman government. Both the Ottoman government and its high official Midhat Paşa were well aware that the brigands were assisted by the Russian government for the purposes of disrupting the stability of the region and the progress of the Tanzimat. ${ }^{102}$ In the context of these letters, Russian propaganda aimed to cause suspicion amongst the Orthodox Christian about the efficiency of Tanzimat reforms.

The Ottoman administration was deeply worried about the activities of Ignatiev and the Slavic Benevolent Committee discussed above. These pan-Slavic activities had become so disturbing that the Ottoman bureaucracy developed plans to counter their influence. The Ottoman archives and memoirs reveal the Porte's uneasiness with pan-Slavism in the Balkans. In this context, Midhat Paşa developed a number of means to counter these activities, the prominent example being the Tuna vilayet reforms. In a similar manner to Gorchakov, the Porte preferred to avoid any tension that would disturb the peaceful atmosphere in the Balkan Peninsula. However, such pan-Slavic activities ran counter to this aim.

\section{Conclusion}

The starting point of Russia's foreign policy from the eighteenth century onwards was to eliminate Ottoman influence in the Balkans and strengthen Russia's political and cultural supremacy over the Balkan Slavic peoples, rather than supporting their national consciousness. This mindset was reflected in Ignatiev's efforts and the Slavic Benevolent Committee's activities. As we can observe in the Ottoman archival documents and memoirs, the Ottoman administration was highly suspicious of these efforts, which served to undermine the effectiveness of Tanzimat reforms. Additionally, European states tried to warn the Porte about the danger posed by these activities on a number of occasions in order to prevent the success of Russia's plans in the Balkan Peninsula. Ignatiev played the main role in support of Russia's pan-Slavic intentions in the region. The committee, when it was first formed, focused on humanitarian aid and religious charity, but over time it became more of a Russian propaganda asset. In fact, pan-Slavists lacked any official support from St. Petersburg, since the Russian Foreign Minister Gorchakov strove to avoid any complications with European powers after the Crimean War. It would be an exaggeration to assert that pan-Slavism was the main driving force behind Russian foreign policy in the Balkans during the interwar period. However, the initiatives of Ignatiev and activities of the Slavic Benevolent Committee increased the tension between the Russian and Ottoman governments, which in turn upset the Russian government's strategy to overcome the Paris Peace Treaty's failure in a peaceful atmosphere.

Scholars with an interest in the history of the Balkans and Russo-Ottoman relations evaluate Russia's policies in the region as constituting part of a broader unitary and coherent foreign policy strategy. This study, in contrast, has argued that Russian political aims in the Ottoman Balkans were influenced more by the acts of N.P. Ignatiev and the Slavic Benevolent Committee than they were by the preferences of St. Petersburg. On this point, these two Russian, pan-Slavist actors deserve greater attention in the effort to better 
understand the interwar period of Russo-Ottoman relations and Russia's impact on Balkan nation-building in the late-nineteenth and early twentieth century.

\section{Acknowledgments}

The author would like to acknowledge the support from the Scientific and Technological Research Council of Turkey (TUBITAK) BIDEB - International Doctoral Research Program 2214.

\section{Disclosure statement}

No potential conflict of interest was reported by the author.

\section{Notes}

1. For example: H. Kohn, Panslavism: Its History and Ideology (New York: Vintage Books, 1960); H. Kohn, 'The Impact of Pan-Slavism on Central Europe', The Review of Politics, Vol.23 (1961); L. Levine, 'Pan-Slavism and European Politics', Political Science Quarterly, Vol.29 (1914), pp.66486; M.B Petrovich, The Emergence of Russian Panslavism, 1856-1870 (New York: Columbia University Press, 1956); G.C. Guins, 'The Degeneration of Pan-Slavism', American Journal of Economics and Sociology, Vol.8 (1948), pp.50-9; G.C. Guins, 'The Politics of Pan-Slavism', American Journal of Economics and Sociology, Vol.8 (1949), 125-32.

2. B.H. Sumner, 'Russia and Panslavism in the Eighteen-Seventies', Transactions of the Royal Historical Society, Fourth Series, Vol.18 (1935); Kohn, Panslavism; Kohn, 'The Impact of Pan-Slavism'.

3. Ö. Kapıcı, 'Osmanlı-Rus illişkilerinde N.P. İgnatyev Dönemi ve Rusya'nın Osmanlı Siyaseti (18641877)' (PhD thesis, Hacettepe Üniversitesi, 2013); V.M. Khevrolina, Nikolai Pavlovich Ignatiev, Rossiiskii Diplomat (Moscow: Kvadriga, 2009); D. MacKenzie, Count N.P. Ignat'ev: The Father of Lies? (New York: Columbia University Press, 2002).

4. D. Vovchenko, 'Modernizing Orthodoxy: Russia and the Christian East (1856-1914)', Journal of the History of Ideas Vol.73 (2012), pp.295-317; D. Vovchenko, 'Containing Balkan Nationalism Imperial Russia and Ottoman Christians, 1856-1912' (PhD thesis, University of Minnesota, 2008); J. Milojkovic-Djuric, Panslavism and National Identity in Russia and the Balkans, 18301880 (New York, Columbia University Press, 1994).

5. S.A. Nikitin, Slavianskie Komitety v Rossii v 1858-1876 godakh (Moscow: Izdatelstva Moskovskogo Universiteta, 1960); A.A. Popovkin, 'Slavianskie Blagotvaritel'nie Obshestva v Moskve i Sankt-Peterburge (1858-1912 gg.)' (PhD thesis, Voronezhskii Gosudarstvennii Universitet, 2013); Z. Zlatar, 'For the Sake of Slavdom. II. M.P. Pogodin and The Moscow Slavic Benevolent Committee: A Collective Portrait of 1870', East European Quarterly, Vol.40 (2006), pp.255-91.

6. A. Adreev, Russkite Slavianski Komiteti i Blgarskoto Vzrozhdensko Obshestvo (1857-1878), (Veliko Trnovo: Abagar, 2014).

7. In this study the names of Russian monarchs will be Anglicised; all other names will be transliterated.

8. For Russia's role in the Napoleonic Wars, see D. Lieven, Russia Against Napoleon: The Battle for Europe, 1807 to 1814 (London: Penguin, 2009).

9. For an overview of Russia's economic and military backwardness, see B.D. Wolfe 'Backwardness andlndustrialization in Russian History and Thought', Slavic Review, Vol.26 (1967), pp.177-203. H.J. Ellison, 'Modernization in Imperial Russia: Purposes and Achievements', The Journal of Economic History, Vol.25 (1965), pp.523-40.

10. The most harmful terms of the Paris Peace Treaty, from Russia's perspective, were the full demilitarisation of the Black Sea and Danube and the protection of Orthodox Christians. As a result of the treaty, Russia saw its power decrease in the Mediterranean and also lost control of Bessarabia. See F. Splidsboel-Hansen, 'Past and Future Meet: Aleksandr Gorchakov and Russian Foreign Policy', Europe-Asia Studies, Vol.54 (2002), pp.380-1. 
11. In his correspondence with Ignatiev, for example, Gorchakov stressed the need not to interfere with the rights of Ottoman Christians, as doing so would damage Russia's relations with European countries; for a case in point, see Russian Federation State Archive (Gosudarstvennyi Arkhiv Rossiiskoi Federatsii), Moscow (hereafter GARF), f.828, first expedition, op.1, d.1434, 149.

12. Galen Blaine Ritchie, 'The Asiatic Department during the Reign of Alexander II, 1855-1881' (PhD thesis, Columbia University, 1970), p.374.

13. Ibid., p.369.

14. GARF, f.1750, first expedition, op.1, d.64, 53; GARF, f.1750, first expedition, op.1, d.70, 21, 56; Ritchie, 'The Asiatic Department', p.385.

15. D. Geyer, Russian Imperialism: The Interaction of Domestic and Foreign Policy 1860-1914 (New York: Berg, 1987), pp.60-1.

16. Nikolai Pavlovich Ignatiev's notes on his foreign policy evaluations, including Balkan policy, can be found in GARF under fond relating to the correspondences and notes of N.P. Ignatiev: GARF, f.730, first expedition, op.1, d.543 (five microfilms) and GARF, f.730, first expedition, op.1, d.544 (four microfilms). These notes were published in Sophia in the 48th and 54th volumes of the collection of 'Arkhivite Govariat'. For details, see Graf N.P. Ignatiev, Arkhivite govoriat No. 54\&48 Diplomaticheski zapiski (1864-1874) \& Doneseniia (1865-1876), Iliia Todev (ed.) (Sophia: Derzhavnaia Agentsiia Arkhivi, 2009). Ignatiev's notes in GARF. f.730 are identical copies of the Sophia publication, except the later includes an added section on 'Donesenie' (beginning from the 775th page), consisting of material from the RGIA - Rossiiskii gosudarstvennyi istoricheskii arkhiv (Russian State Military-History Archive) and AVPRI - Arkhiv vneshnei politiki Rossiiskoi Imperii (Archive of Foreign Policy of the Russian Empire). Additionally, his notes, which were first published in the Russian Foreign Office journal Izvestiia Ministerstva Inostrannykh Del between 1914 and 1915, were gathered together and translated into Bulgarian. See N.P. Ignatiev, Zapiski (1875-1878), V. Dmitrova (trans.) (Sofia: Otechestvennaia Front, 1986).

17. Leonid I. Strakhovsky, 'General Count N.P. Ignatiev and the Pan-Slav Movement', Journal of Central European Affairs, Vol.17 (1957), p.223.

18. Kohn, 'The Impact of Pan-Slavism', p.323; Levine, 'Pan-Slavism and European Politics', pp.665-7.

19. For details on 'United Slavs', see M.B. Nechkina, Dekabristy (Moscow: Nauka, 1982), pp.98-104.

20. Levine, 'Pan-Slavism and European Politics', pp.668-70.

21. Kohn, Panslavism: Its History and Ideology, pp.77, 173.

22. D. Vovchenko, 'Gendering irredentism? Self and other in Russian Pan-Orthodoxy and PanSlavism (1856-85)', Ethnic and Racial Studies, Vol.34 (2011), pp.250-1.

23. Ignatiev, Zapiski (1875-1878), pp.51, 64; Vovchenko, 'Gendering irredentism?', pp.250-1; Kohn, 'The Impact of Pan-Slavism on Central Europe', p.323.

24. H. Seton-Watson, The Decline of Imperial Russia, 1855-1914 (London: Methuen, 1952), pp.90-3.

25. S. Rabow-Edling, Slavophile Thought and the Political Cultural Nationalism (Albany, NY: State University of New York Press, 2006), pp.135-7.

26. Sumner, 'Russia and Panslavism', pp.26-7.

27. Rabow-Edling, Slavophile Thought and the Political Cultural Nationalism, pp.1359-7.

28. 'Vseslavianskii tsar' is a term used by the nineteenth-century Russian poet F.I Tiutchev in his poem 'Prorochestvo'. See F.I. Tiutchev, Lirika, K.V. Pigarev (ed.) (Moscow: Nauka, 1966), p.120; J. Lavrin, 'The Slav Idea and Russia', Russian Review, Vol.21, No.1 (1962), p.11.

29. Guins, 'The Degeneration of Pan-Slavism', p.51.

30. Ignatiev, Zapiski (1875-1878), pp.49-56.

31. Gorchakov was a product of the European-minded education system and the Russian Army, which was under German influence. Therefore, his policies inclined towards maintaining peace and balance with the European states, and thus generally opposed to Ignatiev's aggressive efforts.

32. Gorchakov's concern with the disturbed relations with the European powers was also expressed by his contemporary, the Ottoman historian Ahmed Saib. Saib stated that Russia did not want to risk its relations with Europe until the general situation had turned to Russia's advantage. See Ahmed Saib, Şark Meslesi, Saadettin Gömeç (ed.) (Ankara: Akçağ Yayınları, 
2000), p.32, for the first edition of Saib's work see Ahmed Saib, Tarih-i Meşrutiyet ve Şark Meselesi Hâzırası (Dersaadet: 1328).

33. These Pan-Slavic journals, such as Den, Moskvich, Parus and Moskva, were unpopular among the bureaucracy, and were frequently censured. M.S. Anderson, The Eastern Question (New York: St. Martin's Press, 1966), p.171.

34. Kohn, Pan-Slavism, pp.126-7.

35. See GARF, f.828, first expedition, op.1, d.1434, 149; GARF, f.828, first expedition, op.1, d.1434, 230-2; GARF, f.828, first expedition, op.1, d.1435, 6-8.

36. At the 1867 Congress, when the tsar met with Czech historian Frantisek Palacky and publicist Frantisek Ladislav Rieger, he avoided discussing politics. See Guins, 'The Politics of "PanSlavism"', p.126.

37. Ignatiev's audacity in this regard derived partly from the support he received from Russian aristocracy from the very beginning of his military and diplomatic career. Ignatiev came from a well-known family whose roots went back to the fourteenth century. His royal blood brought him the title of 'Count' in 1877. Most of the predecessors of the Ignatiev family were military men. His father Pavel Nikholaevich Ignatiev was the General of the Armies and the President of the Committee of Ministers. For more information on his background, see: Khevrolina, Nikolai Pavlovich Ignatiev, p.14; and Strakhovsky, 'General Count N.P. Ignatiev and the Pan-Slav Movement', p.224. In June 1861, Ignatiev married Princess Ekaterina Golitsina, great-granddaughter of Marshal Mikhail Kutuzov, the Russian commander who destroyed the Grand Army of Napoleon I in 1812. In addition to his surname, which earned him respect among high-rank officials, this marriage brought him the support of the Russian aristocracy. On this point, see MacKenzie, Count N.P. Ignat'ev, p.203. From the very beginning of Ignatiev's appointment to Constantinople, Gorchakov had a great deal of faith in him. Part of Gorchakov's feelings came from his respect for Ignatiev's father. On this point, see: GARF, f.828, first expedition, op.1. d.1434, 295-7; GARF, f.828, first expedition, op.1., d.1435, 76-7. Ignatiev's family connections and success in foreign diplomatic missions brought him respect from the highest ranks of the tsardom. His missions in Khiva, Bukhara and Beijing won him the favour of Tsar Aleksandr II, and led to his appointment as director of the Asiatic Department. On this point, see Ritchie, 'The Asiatic Department', pp.299-300.

38. For Ignatiev's biography and diplomatic career, see: Khevrolina, Nikolai Pavlovich Ignatiev; MacKenzie, Count N.P. Ignat'ev; and Kapıcı, 'Osmanlı-Rus Ilişskilerinde N.P. İgnatyev Dönemi'.

39. Ignatiev, Zapiski (1875-1878), pp.49-56.

40. Nikolai Ignatiev's son Pavel Ignatiev wrote that his father fought not only against Europeans and the Ottoman administration but also against the Russian Ministry of Foreign Affairs. See: Strakhovsky, 'General Count N.P. Ignatiev and the Pan-Slav Movement', pp.231-2; and Ritchie, 'The Asiatic Department', p.429.

41. Midhat Paşa indicated that upon Mahmud Nedim Paşa's elevation to the office of Grand Vizier, Ignatiev found the opportunity to interfere with the palace's internal affairs. He stated that Ignatiev was responsible for the establishment of the Bulgarian Exarchate in 1872 and for the Herzegovinian uprisings of 1875 . Midhat Paşa underlined that Ignatiev and Mahmud Nedim Paşa cooperated during Balkan uprisings to increase Russian influence at the Porte. On this, see: Midhat Paşa, Midhat Paşa'nın Hatıraları (Tabsıra-i Ibret), Osman Selim Kocahanoğlu (ed.), Vol.1 (Istanbul: Temel, 1997), pp.41-8; and Ritchie, 'The Asiatic Department', p.317.

42. Ignatiev, Zapiski (1875-1878), pp.50-6; I.J. Lederer, Russian Foreign Policy (New Haven, London: Yale University Press, 1962), p.434.

43. In Aug. 1861 Ignatiev firstly contacted Ottoman high officials in Constantinople, during the coronation of Sultan Abdul-Aziz.

44. Sumner, 'Russia and Panslavism', p.37.

45. GARF, f.1750, first expedition, op.1, f.352. (16 May 1869).

46. "En effet, la Russie doit toujours avoir la haute main dans les destinées de la presquîle des Balkans et être le ciment qui relie les différentes races coreligionnaires entre elles." See, Graf N.P. Ignatiev, Arkhivite govoriat No.48, p.246. 
47. “Au milieu toutes ces combinaisons politiques...la Russie seule était complètement isolée; elle n'avait aucun point d'appui pour servir de base à son action et son influence sur les Turcs s'était à cette époque presque entièrement éteinte...La résistance héroïque que nous avions opposée aux armées réunies des plus grandes Puissances du monde n'était pas faite pour diminuer notre prestige et notre gloire." See, Graf N.P. Ignatiev, Arkhivite govoriat No. 48, p.8.

48. Ritchie, 'The Asiatic Department', p.317.

49. "...blgrite predstavliavakha zasega samo surov material, bez dostatchno kadri", see lgnatiev, Zapiski (1875-1878), p.57.

50. Secret letter from Ignatiev to Gorchakov, 27 Dec. 1866. Ignatiev, Zapiski (1875-1878), pp.56-64.

51. Ritchie, 'The Asiatic Department', p.319.

52. Strakhovsky, 'General Count N.P. Ignatiev and the Pan-Slav Movement', p.227. The conduct of Near Eastern policy was directly under the responsibility of Gorchakov and the ambassador at Constantinople. Ignateiv's predecessor in Constantinople was Prince A.B. Lobanov-Rastovskii. Unlike Ignatiev, he was not so energetically interested in Ottoman affairs. See Ritchie, 'The Asiatic Department', p.331.

53. Ibid., p.397-9.

54. Ibid., p.331.

55. Ibid., p.318; GARF, f.828, first expedition, op.1, d.1434, 149.

56. The reports and letters concerning the Moscow Slavic Benevolent Committee are located at GARF, f. no. 1750.

57. Nikitin, Slavianskie Komitety v Rossii v 1858-1876 godakh, pp.35-6.

58. Ibid., p.45. The three other branches of the Committee were founded under Pogodin's administration of the Moscow branch. These committees provided support in the form of money and books, especially to divinity schools. They opened Slavic centres in public libraries and donated books to cities in the Balkans. Russian professors gave public lectures and seminars, the proceeds from which were donated to needy Slavs. In 1875-76 Kiev Committee gathered 34,933 roubles to support Montenegrins and Bulgarians. In general, the Moscow Committee and its three other divisions obtained high praises from Ministry of Foreign Affairs, and operated on a budget of up to 1000 silver roubles annually from the Ministry. See Popovkin, 'Slavianskie Blagotvaritel'nie Obshestva', pp.67-85.

59. Zlatar, 'For the Sake of Slavdom', p.255. Nikitin notes that the Moscow Committee was not composed only of Pan-Slavists, but also of people from different classes and views. However, he admits that the archival sources concerning the details of members have not been preserved, and that therefore much cannot be said about the pan-Slavic views of the members. See Nikitin, Slavianskie Komitety $v$ Rossii v 1858-1876 godakh, pp.40, 57.

60. This network included Russian empress Maria Aleksandrovna, the metropolitan bishop Philaret (Drozdov), the archpriest loann Kronshtatskii (Sergiev), famous Russian writers F.M. Dostoevskii, L.N. Tolstoi and F.I. Tiutchev, famous Russian chemist D.I. Mendeleev, composer P.I. Tchaikovskii, Russian historian and journalist M.P. Pogodin, Slavophile writer I.S. Aksakov, Russian art collectors P.M. and S.M. Tretiakovi, Minister of National Education I.D. Delianov and Russian generals A.A. Kireev, M.G. Cherniaev and R.A. Fadeev. In addition, many historians, specialists of medicine, philologists, philosophers, sociologists, economists and pedagogues were associates of the Moscow Slavic Benevolent Committee. See: Anderson, The Eastern Question, p.171; Sumner, 'Russia and Panslavism', pp.29-34; Popovkin, 'Slavianskie Blagotvaritel'nie Obshestva', pp.4-5.

61. In 1827 Pogodin founded the journal Moskovskii Vestnik which was based on the idea of 'Orthodoxy, Autocracy, Nationality', which was put forward by the minister of education S.S. Uvarov. Between 1841 and 1854 he published Moskovitianin. The main topics of this journal were Russian culture, history and folklore. Popovkin, 'Slavianskie Blagotvaritel'nie Obshestva', pp.67-85.

62. In addition to Pogodin, another prominent name from the committee was Nil Aleksandr Popov, professor at Moscow University. He was seen as a guardian among the Slavs who came to Russia for education. Bulgarians, Serbians and sometimes Czechs and Slovaks, following their arrival in Moscow, would visit Popov to ask for his support. See. Popovkin, 'Slavianskie Blagotvaritel'nie Obshestva', pp.67-85. 
63. Nikitin, Slavianskie Komitety v Rossii v 1858-1876 godakh, pp.36-7; The Tsarist government frequently censored Pan-Slavist publications; however they continued to be issued under different names. These publications included Russkaia Beseda (1856-60), Molva (1857), Parus (1859), Den (1861-65), Moskva (1867-69), Moskvich (1867-68) and Rus (1880-85). See Popovkin, 'Slavianskie Blagotvaritel'nie Obshestva', pp.86-98.

64. GARF, f.1750. first expedition, op.1, d. 64, p.17, 53, 56; GARF, f.1750, first expedition, op.1, d. 70, 2, 21, 45, 57.

65. Popovkin, 'Slavianskie Blagotvaritel'nie Obshestva', p.65.

66. GARF, f.1750. first expedition, op.1, d. 64, p.17.

67. Nikitin, Slavianskie Komitety v Rossii v 1858-1876 godakh, pp.35-6.

68. GARF, f.1750, first expedition, op.1, d.64, 53; GARF, f.1750, op.1, 70, pp.21, 56.

69. For example see, GARF, f.1750, first expedition, op.1, d.227, 12, (16.3.1866)

70. BOA I.MTZ, No.8, 16/Za/1259.

71. The committee supported several institutions in Bulgaria, including the Bulgarian Church and school community (Bolgarskaia Tserkovno-Shkolnaia Obshina), the publication of 'Bulgarian pamphlets' (Bolgarskie Knizhnitsi), and the Bulgarian printing house in Constantinople (Bolgarskaia Tipographia $v$ Konstatinopole), which received the greatest proportion of these donations -800 roubles, almost double what the other institutions received. In the first three of years of its foundation the committee spent a total of 10,000 roubles. See Popovkin, 'Slavianskie Blagotvaritel'nie Obshestva', pp.64-5.

72. GARF, f.1750, first expedition, op.1, d.70, pp.34-5.

73. GARF, f.1750, first expedition, op.1, d.352.

74. GARF, f.1750, first expedition, op.1, d.64, pp.23, 45-7, 53, 67; GARF, f.1750, first expedition, op.1, d.226, 12. The committee paid special attention to the education of Bulgarian women, especially in the 1870s. As an example of this attention, in 1872, Ignatiev helped several Bulgarian girls attain places at the Moscow Aleksandrovskii Monastery. GARF, f.1750, first expedition, op.1, d.64, pp.23, 67.

75. Ignatiev, Zapiski (1875-1878), pp.56-64.

76. The eminent Turkish historian Halil Inalcik suggests that it would be simplistic to say that Balkan uprisings were the direct result of Russian propaganda. He argues that although Russian Pan-Slavism was effective in mobilising local peasants, the immediate cause of uprisings in the Balkans was the taxation policy of the Ottoman gospodarlık regime. For this and more on the Ottoman gospodarlık regime and Russian policy, see Halil Inalcık, Tanzimat ve Bulgar Meselesi (istanbul: Eren, 1992), pp.38-72. The Ottoman archives contain an interesting account of how, in the 1870 s, Ottoman Bulgarian subjects were encouraged by pan-Slavists to emigrate to Russia and Serbia from the region of Rumelia. After a short period they demanded to return home, but upon their return found that their living conditions, which had forced them to quit Ottoman soil in the first place, had grown even worse. On this, see BOA I. MTZ, No.73.16/R/ 1278; BOA I. MTZ, No.79, 1/Ş/1278. For population movements in the Ottoman Balkans in the mid-nineteenth century, see Kemal H. Karpat, Ottoman Population 1830-1914, Demographic and Social Characteristics (Madison: University of Wisconsin Press, 1985), pp.60-77.

77. BOA I. MTZ, No.103, 29/Ca/1285.

78. BOA HR. SYS. No.182 /43, 1-2 (Neue Frei Presse, 8 February 1873).

79. G. Grbesic, 'Od ilirskoga pokreta i jugoslavenske ideje do neuralgicnih tocaka u hrvatskosrpskim odnosima u 20. stoljeccu', Diacovensia, Vol.21 (2013), p.89.

80. L. Leger, Le Monde Slave, Etudes Politique et Literaires (Paris: Librairie Hacette et Cie, 1897), p.126.

81. Ibid., pp.123-8.

82. N. Traikov, Bratia Miladinovi - prepiska, Izdiril, komentiral i redaktiral (Sofia: Blgarskaia Akademiia Nauka, Institut za Istorii, Izdatelstvo na BAN, 1964), pp.257-8.

83. D. Raikov. Istoricheskata cdba na makedonskite blgari Svidetelstva za blgarskoto vzrazhdanie $v$ Makedoniia (Sofia: Makedonski Nauchen Institut, 1997), pp.256-7.

84. The Miladinov brothers worked for the idea of an independent Bulgarian Church. However, after a Greek archbishop in Skopje complained about them, the brothers were taken captive 
by the Ottoman government. Strossmayer sent a letter to the Austrian Minister of Foreign Affairs petitioning his aid, but this proved insufficient to save them. See, V. Roudometof, Nationalism, Globalization, and Orthodoxy, (London: Greenwood Press, 2001), p.144.

85. Bratia Skorpilovi, Pametnitsi iz Blgarsko. chast 1. Trakiia (Sofia: Pridvorna Pechatnitsa na B. Proshek, 1888), p.1.

86. K. Irechek, Kniazhestvo Blgariia, (Plovdiv: Khr. G. Danov, 1899).

87. V. Dinova-Ruseva, 'Mnozhenski aspekti v zhvopista na Mrkvichka', Problemi na Izkustvoto, Vol.3 (2009), pp.14-22.

88. Ignatiev, Zapiski (1875-1878), pp.39-42.

89. Kohn, Panslavism, p.177.

90. This is especially evident in Austro-Hungarian newspapers, such as Fremden-Blatt, La Nouvelle Presse Libre, La Gazette Oficielle and La Gazette Allemande, which warned the Ottomans about pan-Slavic activities and their possible undesirable outcomes. See BOA HR. SYS. 182. 48.3, 1-2, (22 June 1873).

91. BOA HR.SYS. 158. 3., (27 January 1870).

92. This Ottoman administrative division was established in 1864 and lasted until 1878. Midhat Paşa continued his governorship until 1868. For the Ottoman vilayet system and Tanzimat reforms see S.J. Shaw and E.K. Shaw, History of the Ottoman Empire and Modern Turkey, Vol.II, (Cambridge: Cambridge University Press, 1977), pp.55-172 and Halil İnalcık and Mehmet Seyitdanlıoğlu, Tanzimat, Değişim Sürecinde Osmanlı Imparatorluğu (İstanbul: Türkiye iş Bankası Kültür Yayınları, 2012).

93. See Ali Haydar Midhat Bey, The Life of Midhat Pasha (London: John Murray, 1903), pp.32-66; G. YazıcI, 'Midhat Paşa (1822-1884)'s Policies vs. N.P. Ignatiev (1832-1908)'s Pan-Slav Mission' (MA Thesis, Central European University, 2009), pp.31-47.

94. Midhat Paşa, Midhat Paşa'nın Hatıraları, pp.39-40, 60-2.

95. GARF, f.828, first expedition, op.1, d.1434, 149. Gorchakov was warning Ignatiev on acting through the orders coming from St. Petersburg.

96. For the report dated to 9 Dec. 1867, see Toder Panchev (ed.), Iz Arkhivata na Naiden Gerov, Vol.2 (Sofia: Blgarskata Akademiia na Naukite, 1911), p.287.

97. Ignatiev, Arkhivite govoriat No. 48, p.246.

98. Ahmet Midhat Efendi, Üss-i Inkılap, i.N. Uysal (ed.) (istanbul: Dergah, 2013), pp.142-3.

99. BOA i. MTZ, No.96, 2/R/1285.

100. GARF, f. 1750, first expedition, op.1, d.19: 'Ocherk neizvestnogo avtora 'Bolgarskie Haidugsskie druzhini na Balkanakh' (1868), essay of an unidentified author 'Bulgarian Volunteer Bandits in the Balkans', 1-1ob.

101. GARF, f. 1750, first expedition, op.1, d.19, 5-5ob.

102. Midhat Paşa, Midhat Paşa'nın Hatıraları, pp.65-6. 